\title{
Staged subthalamotomy
}

Jeff Elias

From Current and Future Applications of Focused Ultrasound 2014. 4th International Symposium Washington, D.C, USA. 12-16 October 2014

\section{Background/introduction}

A clinical trial is being planned to investigate the management of medication-refractory motor symptoms associated with Parkinson's disease using a unilateral, focused ultrasound subthalamotomy performed in a staged fashion.

\section{Methods}

For this study, ten subjects with medication-refractory symptoms or side effects of advanced Parkinson's disease will be enrolled. Each patient will be treated with a "sub-therapeutic" (stage 1) focused ultrasound subthalamotomy and observed for thirty days.

Those who develop severe and involuntary movements, such as hemiballismus, will be excluded from the second stage procedure. For those who tolerate subthreshold lesioning, a second, full subthalamotomy ablation (stage 2) with focused ultrasound will be performed. Validated Parkinson's disease rating scales, cognitive assessments, and MRI will be obtained before and after the procedures.

Published: 30 June 2015

Submit your next manuscript to BioMed Central and take full advantage of:

- Convenient online submission

- Thorough peer review

- No space constraints or color figure charges

- Immediate publication on acceptance

- Inclusion in PubMed, CAS, Scopus and Google Scholar

- Research which is freely available for redistribution

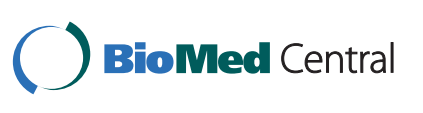

(c) 2015 Elias; licensee BioMed Central Ltd. This is an Open Access article distributed under the terms of the Creative Commons Attribution License (http://creativecommons.org/licenses/by/4.0), which permits unrestricted use, distribution, and reproduction in any medium, provided the original work is properly cited. The Creative Commons Public Domain Dedication waiver (http:// creativecommons.org/publicdomain/zero/1.0/) applies to the data made available in this article, unless otherwise stated. 